\title{
Analysis of Upwelling Events in the Southern South China Sea Using Multi-Mission Satellite Altimeter
}

\author{
Dolhan, A. R. ${ }^{1}$, Din, A. H. M. ${ }^{1,2}$, Pa'suya, M. F. ${ }^{*}$, Hamden, M. H. ${ }^{1}$ and Uti, M. ${ }^{1}$ \\ ${ }^{I}$ Geospatial Imaging and Information Research Group(GI2RG), Faculty of Built Environment and Surveying, Universiti \\ Teknologi Malaysia, 81310 Johor Bahru, Johor, Malaysia \\ ${ }^{2}$ Geoscience and Digital Earth Centre (INSTeG), Faculty of Built Environment and Surveying, Universiti Teknologi \\ Malaysia, 81310 Johor Bahru, Johor, Malaysia \\ ${ }^{3}$ Climate and Environment Change Research Group, Faculty of Architecture, Planning \& Surveying, Universiti Teknologi \\ MARA, Perlis Branch, Arau Campus, 02600 Arau, Perlis, Malaysia
}

\begin{abstract}
Upwelling is a vital ocean behaviour, especially for the Fisheries Industry, where upwelling will help to detect fish ground at a particular ocean area. However, the study of upwelling is minimal and not well understood due to some reasons and constraints, such as limited observation. Upwelling lacks a comprehensive in-situ observation system where it relies on limited information collected from the ground-truthing execution such as ships, buoys, and current meter. This study aims to analyse the upwelling pattern in the southern region of the South China Sea by using a multi-mission satellite altimeter. In order to derive the physical oceanography that involves upwelling, such as sea surface height (SSH), Mean Dynamic Topography (MDT), and the Sea Level Anomaly (SLA), the Radar Altimeter Database System is used. Five Satellite Altimeter mission is used in this study, which is JASON-2, JASON-3, CYROSAT2, SARAL, SENTINAL3A from 2013 to 2017. Validation is made using a statistical method showing a good correlation between Altimetry data and Tidal Data at tide gauge, which is 0.84 to 0.97 , respectively. Also, monthly altimetry derived Geostrophic Current was assessed by analysing the current pattern where it shows a similarity with a previous study where the current velocity is $0.5 \mathrm{~ms}-1$ to $2 \mathrm{~ms}-1$. From the result, eddies can be seen in the seasonal and monthly Absolute Geostrophic Ocean Current (AGOC) map, indicating the present presence of upwelling. In conclusion, this study will benefit other researchers in terms of both upwelling and eddy studies.
\end{abstract}

Keywords: upwelling; satellite altimeter; geostrophic current; RADS; sea surface height

\section{INTRODUCTION}

South China Sea (SCS) is the largest marginal sea in Southeast Asia, with a total area of 3.5 million $\mathrm{km}^{2}$ (Zhuang et al., 2010). Geographically, SCS is connected with the East China sea through the Taiwan Strait, the Pacific Ocean through the Luzon Strait, and the Java Sea through the Karimata Strait. Ocean upwelling studies in the SCS have received greater attention from many research communities to understand this phenomenon (e.g., Xie et. al., 2003;
Villanoy et. al., 2011; Yan et. al., 2015; Akhir et. al., 2015; Ndah et. al., 2016; Yie et al., 2021). Ocean upwelling is one of the essential features of global ocean circulation patterns and plays an important role in supporting fisheries activities, especially in the South China Sea. It is because the ocean upwelling will function to bring the nutrients at the subsurface water to the surface (Cropper et al., 2014), which needs to sustain populations of phytoplankton, the primary source of nutrition of marine fish. Thus, good fishing grounds typically will be found in the upwelling area. 
Typically, the ocean upwelling which occurs at the open sea or coastal area can be driven by many factors such as alongshore wind stress, wind stress curl, bottom topography, coastline orientation, shelf circulation, eddies, islands and capes, and the shape of the coastline (Ndah et al., 2016). Literature records show various approaches have been used to understand the ocean upwelling phenomenon such based on the wind stress curl information (Uti et. al., 2013; Junker et. al., 2015; Desbiolles et. al., 2016; Renault et al., 2016), interactions of coastal currents with topography (Gan et. al., 2009; Wang et et al., 2014), based on the cyclonic eddies activities (Djakouré et al., 2014) and etc.

The advent of the satellite altimeter over the past two decades has been a beacon of our vision in understanding ocean behaviour (Pa'suya et al., 2014a). The sea level anomaly derived from altimetric datasets become beneficial information to study the behaviour of sea level, cyclonic ocean eddies (Faghmous et al., 2015) as well as the ocean current circulation (Pa'suya et. al., 2014b; Rio et. al., 2016; Chafik et al., 2019), which is quite a relation to ocean upwelling phenomenon (Umaroh et al., 2016). The basic principle of a satellite altimeter is based on the premise that time is a distance. The distance between the satellite and the ocean surface is measured using the satellite radar discharged from the round-trip travel time of microwave pulse. More than 1700 pulses per second are capable of the most accurate high-frequency satellite altimeter, and the echo will be reflected in the ocean and back onboard. However, according to Chelton et al. (2001), the utilisation of the independent tracking system is to calculate the satellite's three-dimensional position with reference to a fixed earth coordinate system. Combining these parameters will produce a profile of sea surface height or sea level with reference ellipsoid. Figure 1 shows an overview of the principle of a satellite altimeter. Independent tracking systems are used to determine the satellite's position with respect to the Earth's fixed coordinate system, including laser ranging stations, Doppler Orbitography and Integrated Satellite Radio Positioning (DORIS), and onboard Global Positioning System (GPS). However, getting the value of the water height is not simple, and in practice, it is much more complex (Fu \& Chelton, 2001; Hamid et al., 2018). For example, atmospheric correction (ionosphere, dry troposphere, and wet troposphere), orbital altitude (altimeter range and instrument correction), sea state bias, pole tide, ocean tide, ocean tide charging electromagnetic bias, and dynamic atmosphere are a few factors that must be taken into account.

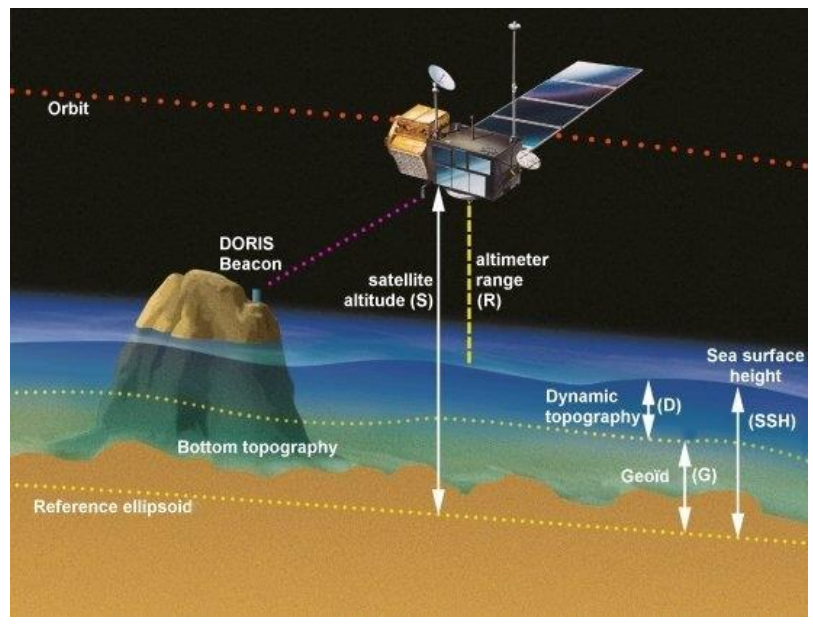

Figure 1. Overview of the satellite altimeter principle

(AVISO, 2019)

The present study aimed to understand ocean upwelling based on cyclonic eddies derived using altimetric datasets for five (5) years. The study area covers the southern region of SCS and partially covers the gulf of Thailand $\left(0^{\circ} \mathrm{N}-10^{\circ} \mathrm{N}\right.$ latitude, $95^{\circ} \mathrm{E}-120^{\circ} \mathrm{E}$ longitude) as shown in Figure 2.

\section{MATERIALS AND METHOD}

\section{A. Multi-mission Satellite Altimeter Data Processing}

Since 1991, ERS-1, TOPEX/POSEIDON, ERS-2, Geosat Follow on, Jason-1, and Envisat missions have been continuously accessible for satellite altimeter estimation. From these satellite estimations, it has altered our understanding towards the ocean from the study of ocean sea level and climate variability. In 1992, satellite altimetry TOPEX / Poseidon was launched, and its mission lasted until October 2005. Its original ground track was overtaken in 2002 by its JASON-1 successor. Both satellite missions provide the most accurate altimetry data compared to others, mainly due to the precise determination of the orbit. The ground track pattern of these satellites repeats every 10 days, with this temporal sampling providing near-global (within \pm $66^{\circ}$ latitude) maps of sea level changes (Din et al., 2014). Although satellite altimeter records are still relatively short 
compared to the tide gauge data sets, this technique seems provides excellent spatial coverage of the sea level quite promising for the sea level change problem as it measurement (Maximenko et. al., 2009; Din et al., 2019).

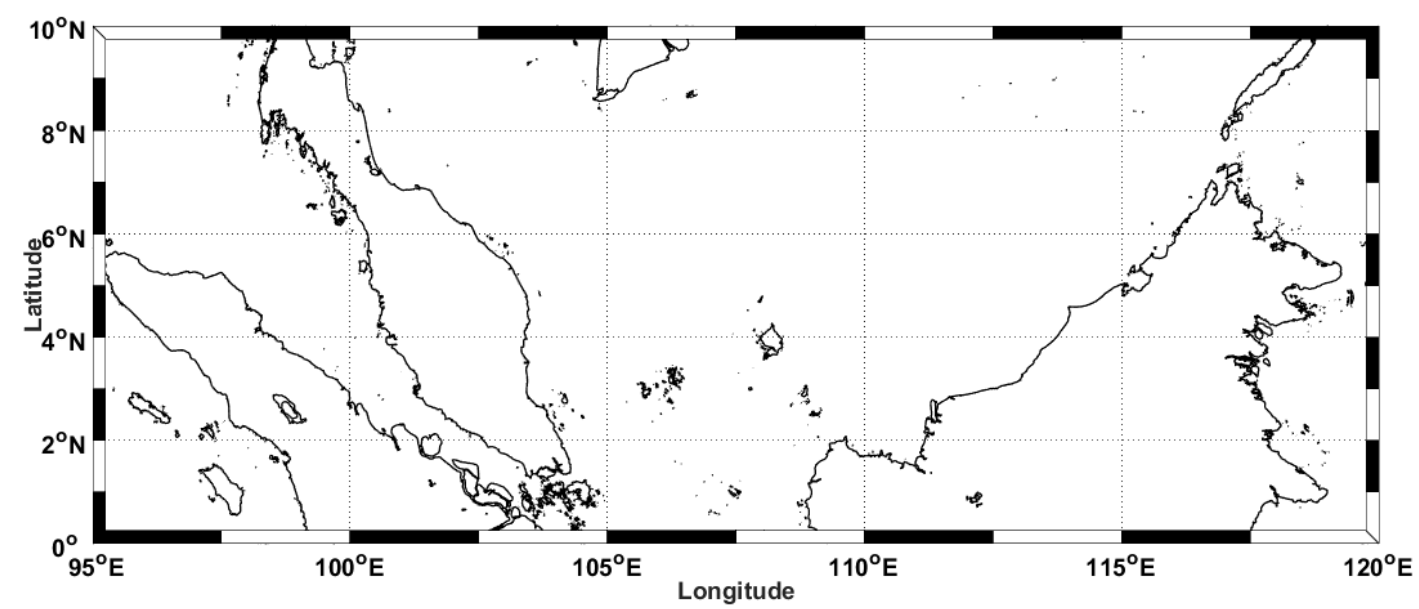

Figure 2. Study area

Meanwhile, the European Space Agency (ESA) has individually propelled the ERS satellites ( 1 and 2 between 1991 and 1995). These satellites were the main missions to obtain monetarily accessible information on microwave radars, offering new open doors for remote all-climate detection applications. Both were propelled into a sunsynchronous orbit at a tendency of $98^{\circ}$ and an elevation somewhere in the range of 782 and $785 \mathrm{~km}$, rendering them less appropriate for concentrations of marine tide and increasingly impotent to environmental drag, resulting in slightly less orbit precision. ESA propelled the Environmental Satellite (Envisat) in March 2002, an advanced polar-circular earth perception satellite that provides climate, sea, land, and ice estimates. This satellite mission, which succeeds the ERS satellites, is still operational (Ducet et al., 2000). In this research, the sea level anomaly used to derive the ocean current is processed using the Radar Altimeter Database System (RADS), the TUDelft, NOAA, and Altimetrics LLC archiving and processing initiative (Naeije et al., 2000). An autoprocessing system is used to extract and process the 5 years of altimetric data from 4 satellite missions. Basically, there are three (3) main steps in the altimetric data processing using RADS to yield sea level anomaly (Figure 3), namely altimeter correction and bias removal, crossover minimisation, and data filtering. After processing, the sea level anomaly from the 4 satellite missions will be averaged

and gridded into 0.25 degrees $x \quad 0.25$ degrees. In the crossover minimisation process, the sea level anomaly from different satellite missions needs to be adjusted to a "standard surface" due to the incoherence of the satellite orbit frame and orbital frame.

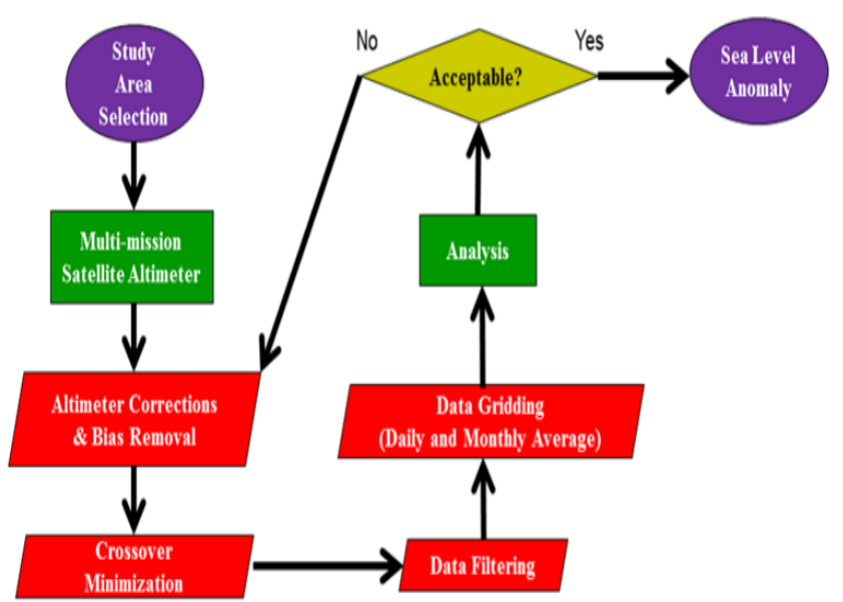

Figure 3. Processing flow of RADS (Din et al., 2014)

Because of its high precision orbit, Jason-2 has been applied as the standard surface for processing integrated data. Details of the satellite used in this study are listed in Table 1, and Figure 4 shows the SLA pattern over the study area. 
Table 1. List of satellite altimeter

\begin{tabular}{ccccc}
\hline Altimeter & Agency & Phase & Cycle & Period \\
\hline & & A & 000-303 & \\
Jason-2 & NASA/ CNES & C & $332-355$ & JUL 2008 - DEC 2017 \\
& & D & $356-364$ & \\
Jason-3 & NASA/ CNES & A & 000-103 & FEB 2016 - DEC 2017 \\
Cryosat-2 & ESA & A & 004-112 & JUL 2010 - DEC 2017 \\
Saral & ISRO/ CNES & A & o01-035 & MAR 2013 - DEC 2017 \\
Sentinel-3A & & B & 036-061 & \\
& ESA & A & o01-038 & MAR 2016 - DEC 2017
\end{tabular}

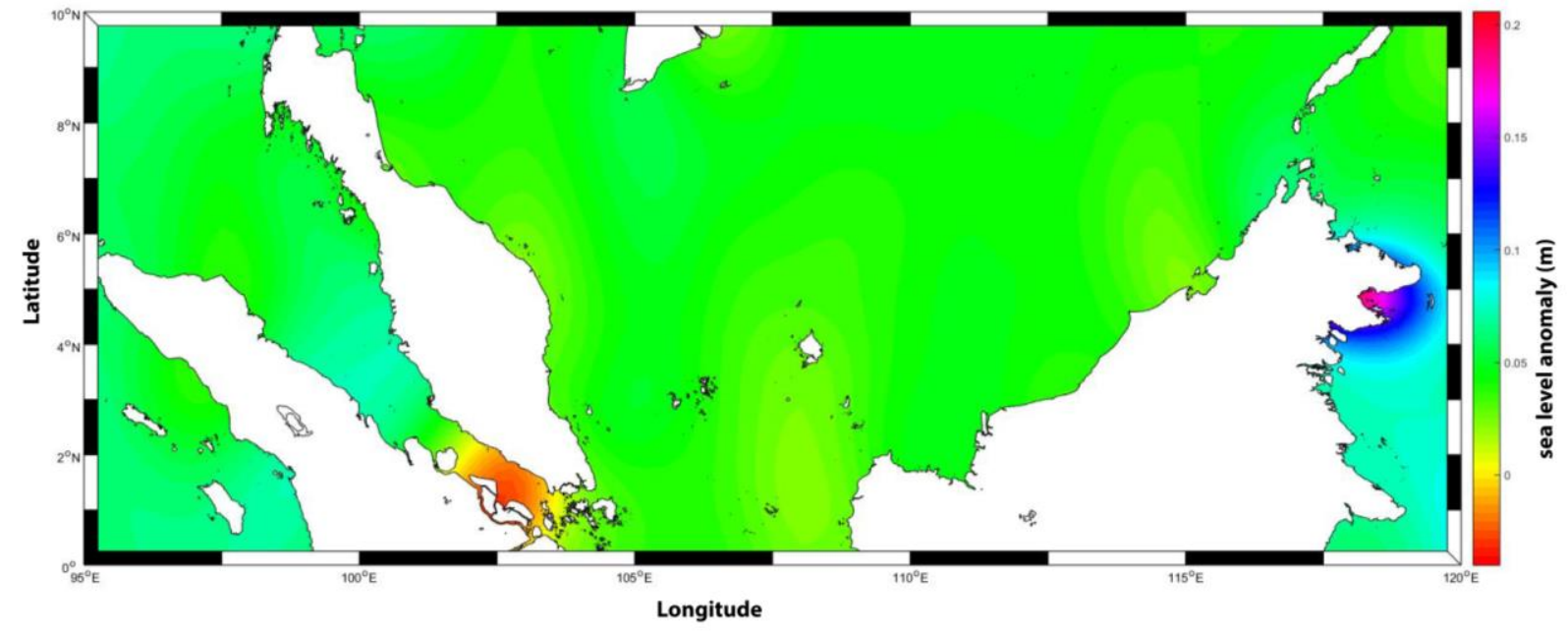

Figure 4. Gridded sea level anomaly derived from RADS

\section{B. Derivation of Geostrophic Current for Upwelling}

The corrected and gridded sea level anomaly that has been processed from RADS is used to estimate the geostrophic current anomaly based on the geostrophic balance, which derived from the relationship of pressure gradient and the Coriolis force by using the equation of Pickard et al. (1990) as follows:

$$
\begin{aligned}
& f v=\frac{1}{p} \times \frac{\delta p}{\delta x} \\
& f u=\frac{1}{p} \times \frac{\delta p}{\delta y}
\end{aligned}
$$

where the $p$ is the ocean pressure, $u$ and $v$ are the horizontal velocities in the $\mathrm{x}$ and $\mathrm{y}$ direction, $\rho$ is the sea-water density, and $f$ is the Coriolis force parameter defined as:

$$
f=2 \Omega \sin \varphi
$$

where $\Omega$ denotes the rate of rotation of the earth $(7.292511 \mathrm{x}$ 10-5) and $\Phi$ is Latitude. Since the pressure gradient is proportional to dynamic ocean topography slope, $\zeta$ and $(\mathrm{p}=$ $\rho g \zeta$ ), both the equations above become as below (Zhuang et. al., 2010; Pa'suya et al., 2014a):

$$
u=\frac{g}{f} \times \frac{\delta \zeta}{\delta \mathrm{y}} \quad v=\frac{g}{f} \times \frac{\delta \zeta}{\delta \mathrm{x}}
$$

where $\mathrm{g}$ is the local acceleration of gravity and $\zeta$ is sea level anomaly. Since the Coriolis force reduces to zero near the equator, the estimation of geostrophic current is limited to the region from $1.750 \mathrm{~N}$. In order to derive absolute geostrophic current, the mean geostrophic current derived from DTU15 Mean Dynamic Ocean Topography are added to the geostrophic current anomaly to produce absolute geostrophic current. 
Table 2. Six selected tide gauge

\begin{tabular}{|c|c|c|}
\hline Location & Latitude & Longitude \\
\hline Bintulu & $03^{\circ} 15^{\prime} 44^{\prime \prime}$ & $113^{\circ} 05^{\prime} 50^{\prime \prime}$ \\
\hline Cindering & $05^{\circ} 15^{\prime} 54^{\prime \prime}$ & $103^{\circ} 11^{\prime} 12^{\prime \prime}$ \\
\hline Tioman & $02^{\circ} 48^{\prime} 26^{\prime \prime}$ & $104^{\circ} 08^{\prime} 24^{\prime \prime}$ \\
\hline Geting & $06^{\circ} 13$ '35" & $102^{\circ} 06^{\prime} 24^{\prime \prime}$ \\
\hline Tanjung Sedili & $01^{\circ} 55^{\prime} 54^{\prime \prime}$ & $104^{\circ} 06^{\prime} 54^{\prime \prime}$ \\
\hline Labuan & $05^{\circ} 16^{\prime} 22 "$ & $115^{\circ} 15^{\prime} 06^{\prime \prime}$ \\
\hline
\end{tabular}

\section{Altimeter Data Verification}

In order to verify the accuracy of sea level anomaly before the derivation of geostrophic current, the sea level derived from RADS was compared with the tidal data measured at six (6) tide gauge stations in the Peninsular Malaysia and Borneo (Sabah and Sarawak). All of the data was provided by Jabatan Ukur dan Pemetaan Malaysia (JUPEM) through Permanent Service Mean Sea Level (Din et. al., 2017; PSMSL, 2019). The gridded sea level anomaly was interpolated onto the tide gauge location (Table 2) using Inverse Distance Weighted interpolation (IDW) methods based on the four nearest points as follows:

$$
\zeta^{\prime}=\frac{W_{1} \zeta_{1}+W_{2} \zeta_{2}+W_{3} \zeta_{3}+W_{4} \zeta_{4}}{W_{1}+W_{2}+W_{3}+W_{4}}
$$

where $\zeta^{\prime}$ is the unknown value of sea level anomaly at a location to be determined and $\zeta_{1-4}$ is the nearest known point value. The $W$ is the weight which can be computed as follows:

$$
W=\frac{1}{\text { Distance }}
$$

\section{RESULT AND DISCUSSION}

\section{A. Sea Level Data Verification between Multi- mission Altimeter and Tide Gauge}

The root mean square error (RMSE) and correlation coefficient between both methods (satellite and tide gauge) were computed to assess the accuracy of the sea level anomaly and summarised in Table 3. Meanwhile, the variation pattern of sea level between tide gauge and altimeter is shown in Figure 5. The result clearly shows the variation pattern of sea level between tide gauge and altimeter in a good qualitative agreement is found between the two sea level estimates with correlation, $\mathrm{R}=0.84$ to 0.97 and RMSE $=0.028-0.046 \mathrm{~m}$. The consistency in the pattern and high correlation indicates good agreement between tide gauge and altimetry data.

Table 3. Summary of the correlation and RMSE between Satellite Altimeter and tide gauge

\begin{tabular}{ccc}
\hline Location & Correlation & RMSE \\
\hline Bintulu & 0.84 & 0.032 \\
Cindering & 0.94 & 0.037 \\
Tioman & 0.94 & 0.046 \\
Geting & 0.97 & 0.041 \\
Tanjung Sedili & 0.92 & 0.038 \\
Labuan & 0.93 & 0.028 \\
\hline
\end{tabular}

\section{B. Geostrophic Current Circulation}

Geostrophic currents are computed from the 5 years averaged SLA (1993-2011) and plotted based on the monsoon season (Table 4) and monthly averaged. Here, each season is defined as north-east monsoon (NE) from November to February and south-west monsoon (SW) from May to August, in terms of monsoon variations.

Table 4. Monsoon season period

\begin{tabular}{cc}
\hline Monsoon & Month Period \\
\hline Northeast Monsoon & November - February \\
Southwest Monsoon & May - August \\
First Inter-Monsoon & March - April \\
Second Inter-Monsoon & September - October \\
\hline
\end{tabular}

The geostrophic current during the Northeast monsoon (NE) based on 5 years altimetric datasets is shown in Figure 6. During the NE monsoon, it is shown that there is a cyclonic eddy occurring northeast of the Natuna Island at approximately $\left(6^{\circ} \mathrm{N}, 110^{\circ} \mathrm{E}\right)$ where the current is moving anti-clockwise, which indicates an upwelling (U) is present in that area during the NE monsoon. 


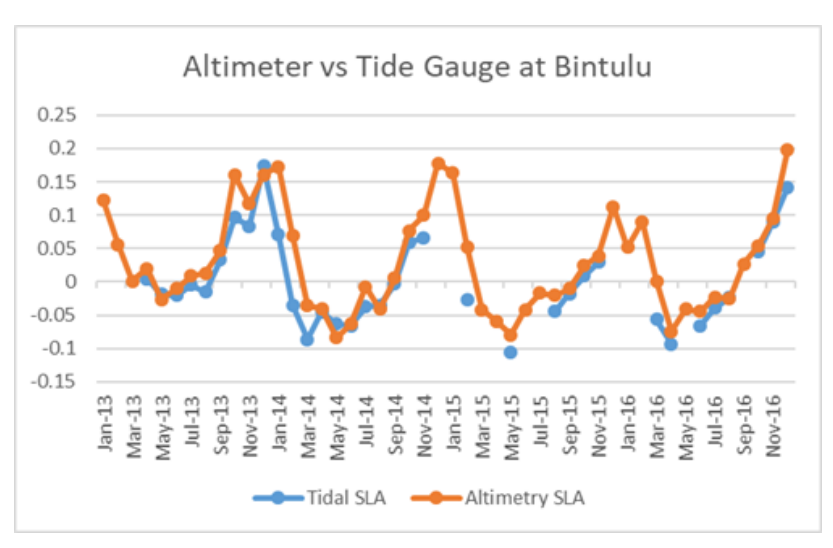

Altimetervs Tide Gauge at Cendering
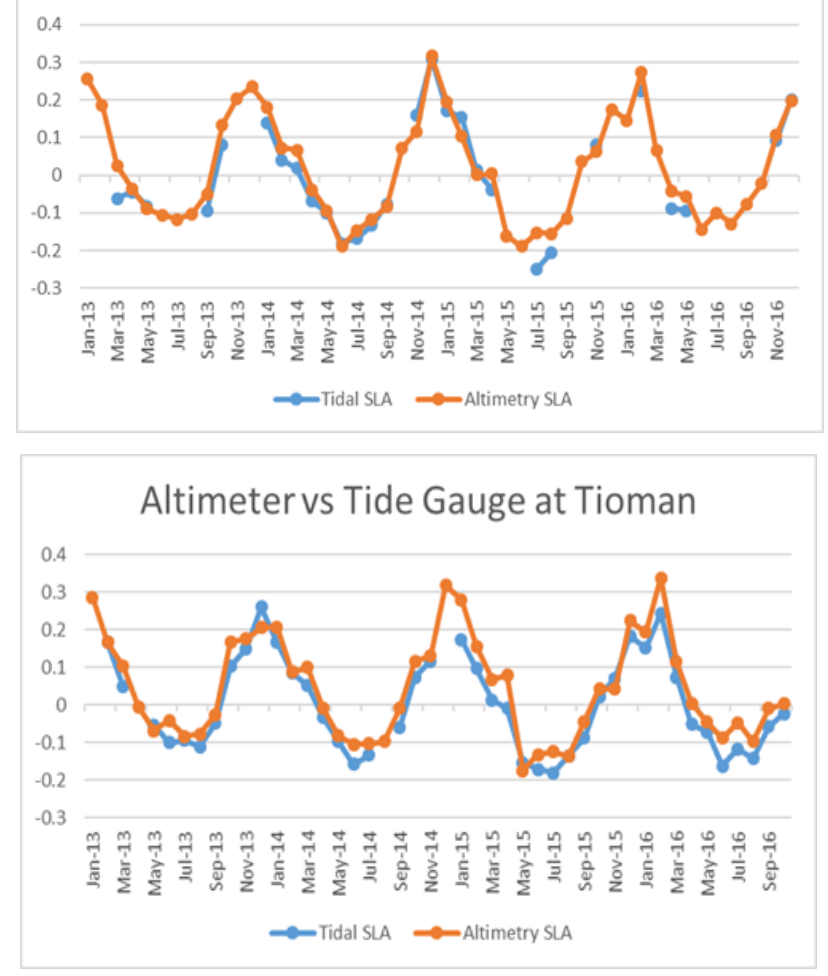

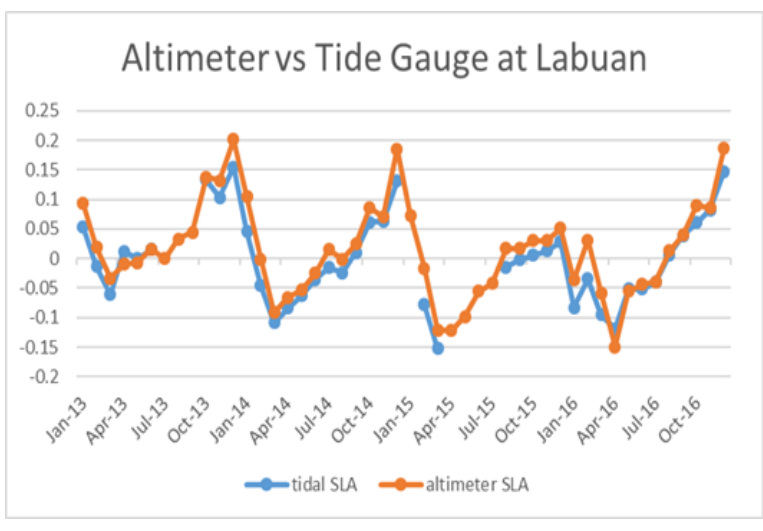

Altimeter vs Tide Gauge at Tanjung Sedili
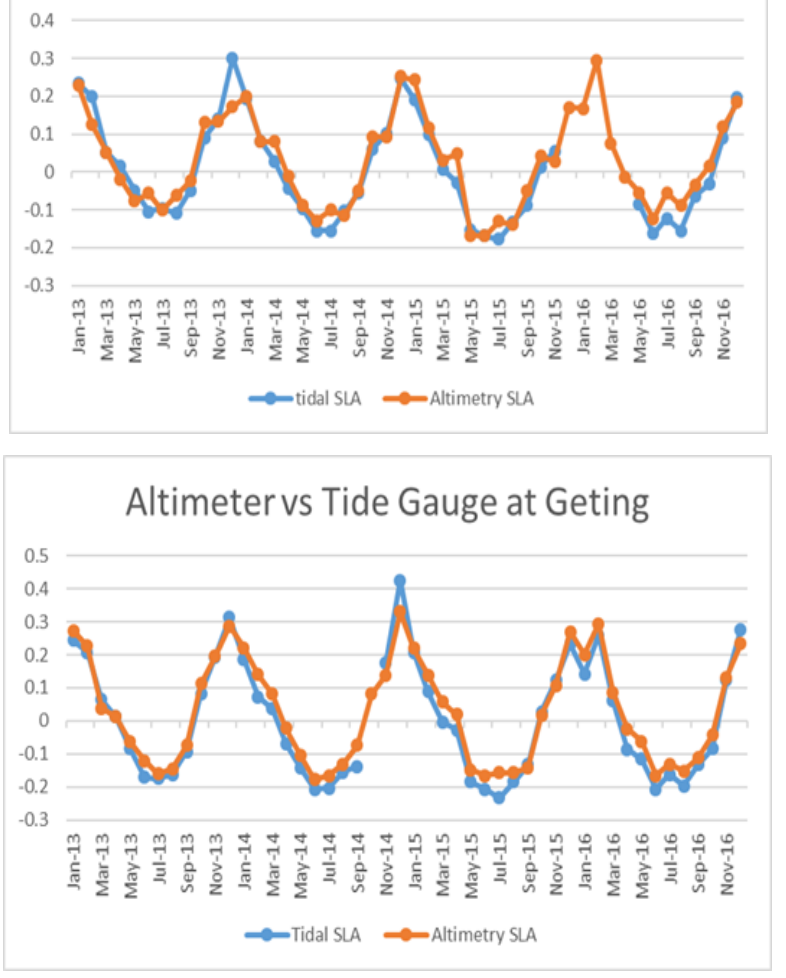

Figure 5. Comparison of SLA from Satellite Altimeter data and Tide gauge at 6 selected Tide Gauge

This is probably due to the Vietnam Coast Current leaving the Vietnam Coast and splitting into two directions. One of the directions is moving eastward toward the Natuna and Borneo Island. However, many anti-cyclonic eddies occur in the SSCS during NE monsoon, which indicates the presence of downwelling (D) at the southern part of Borneo, where the current at that area split $\left(4^{\circ} \mathrm{N}, 114^{\circ} \mathrm{E}\right)$ into two directions, and forms an anti-cyclonic eddy and downwelling. For the Gulf of Thailand, there is also an indication that a downwelling occurs because, during the NE monsoon, the current flow is an anti-cyclonic eddy. This is because of the geometry of the coastal area, which affects the northward movement of the current (Pa'suya et al., 2014b).

The geostrophic current during the SW monsoon is shown in Figure 7. The result shows that the current flow is almost an inverse of the current flow in the NE monsoon, where the ocean current flows from south to north. This finding is consistent with that of Akhir (2012) who studied the ocean current using Global Ocean Model (OCCAM). 


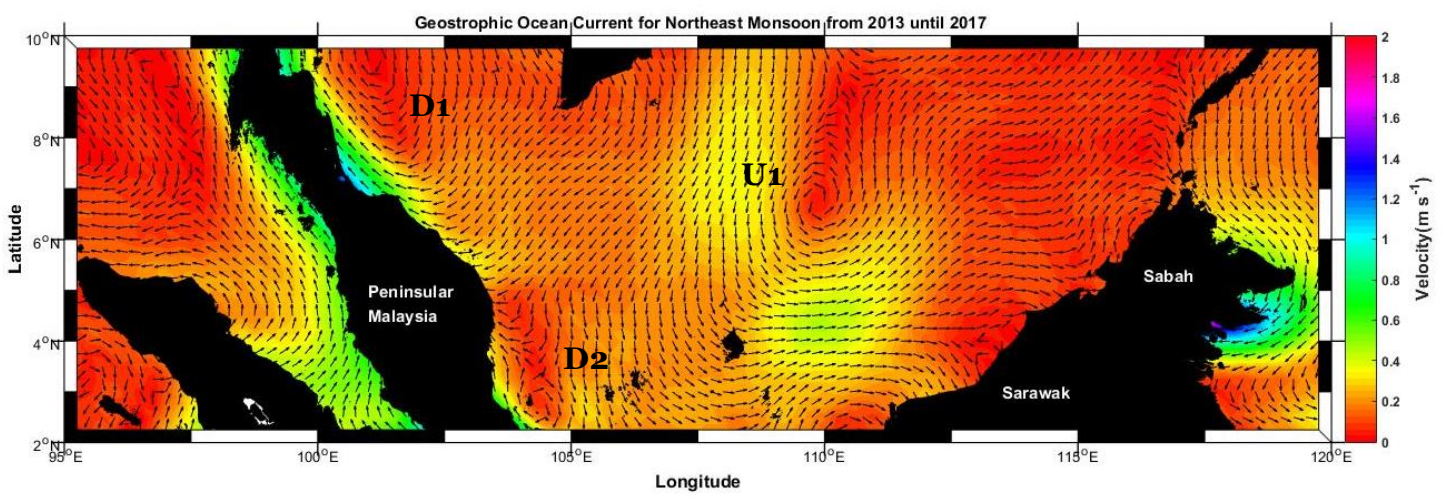

Figure 6. Surface Geostrophic current during Northeast Monsoon

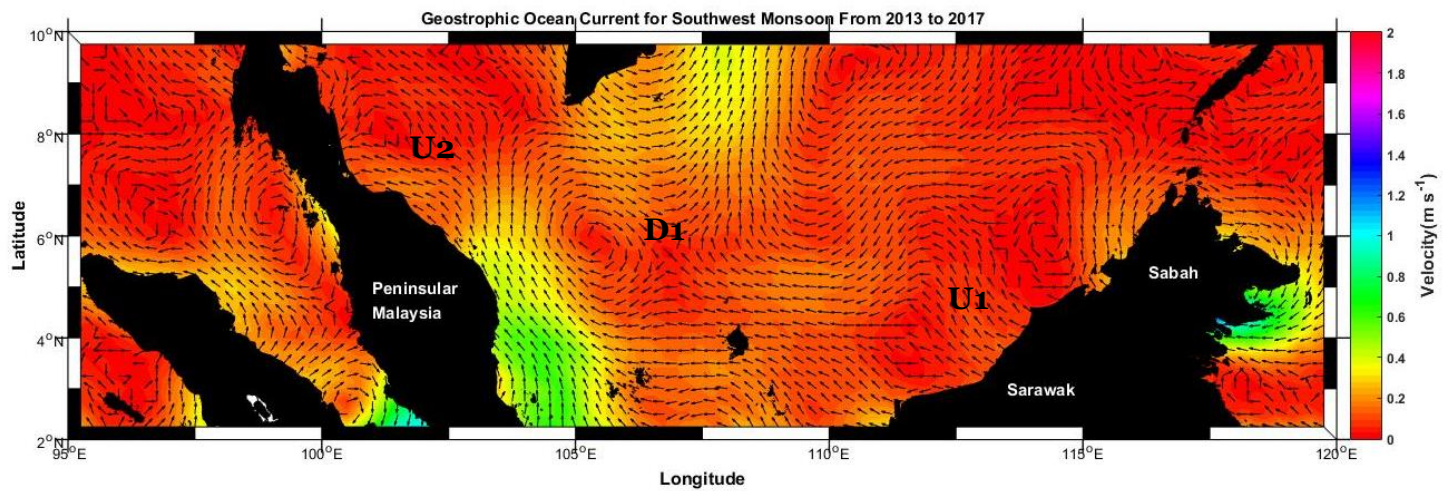

Figure 7. Surface Geostrophic current during Southwest Monsoon

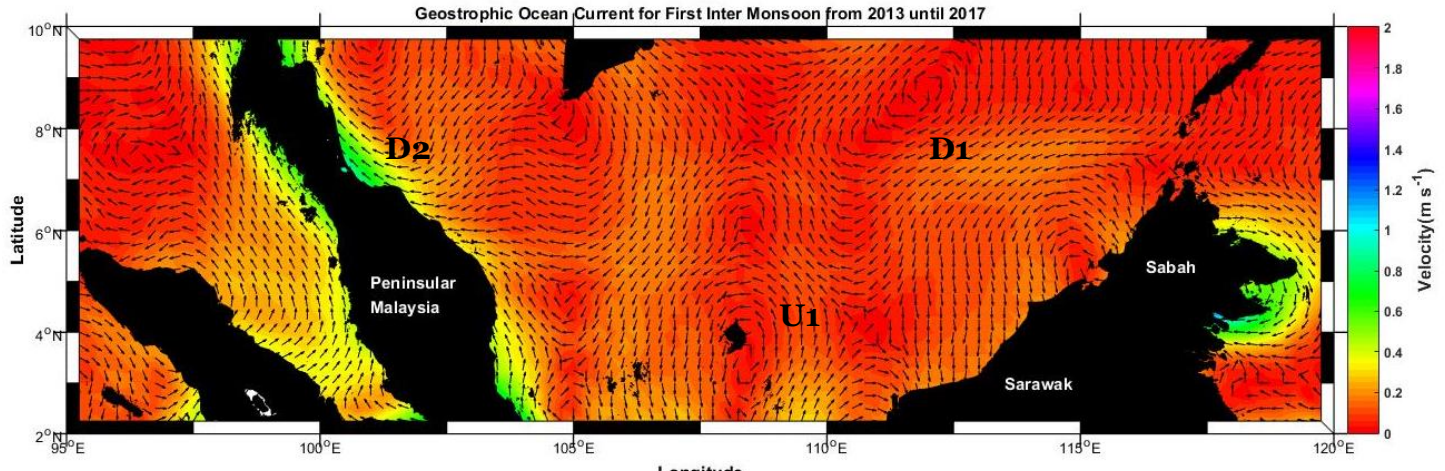

Figure 8. Surface Geostrophic current during First-inter Monsoon

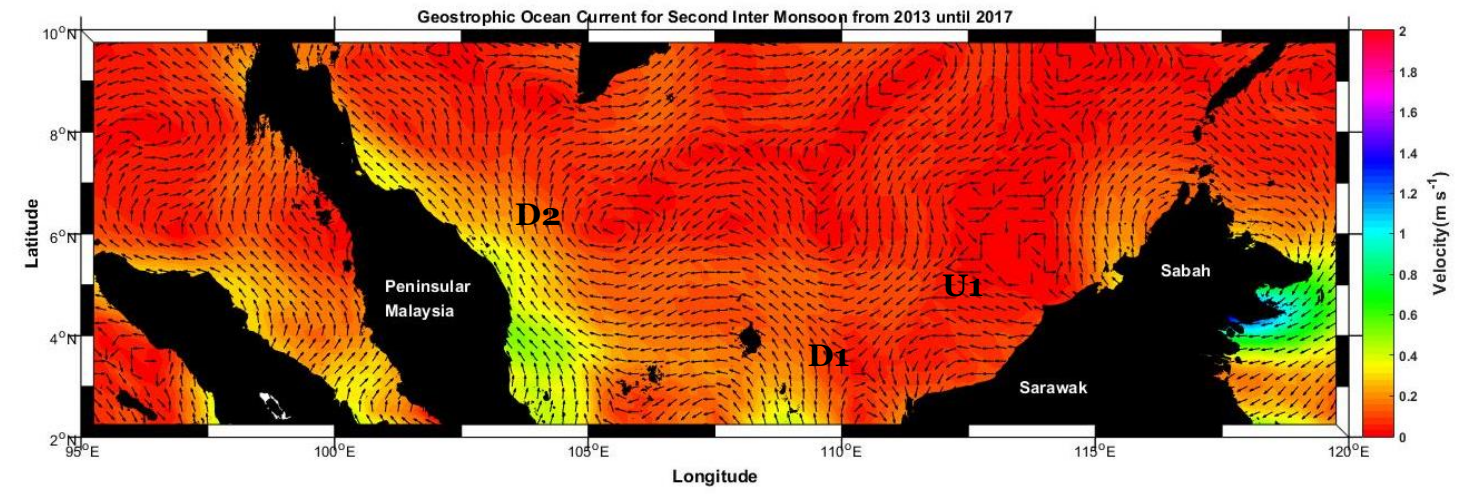

Figure 9. Surface Geostrophic current during Second-inter Monsoon 
The ocean current flows from the Karimata Strait, moving northward along the Peninsular Malaysia coast. An anticyclonic eddy (D) has formed at $6^{\circ} \mathrm{N}, 105^{\circ} \mathrm{E}$. Concurrent, an upwelling (U) near the coast of Borneo (U1) and the Gulf of Thailand (U2). Figure 8 shows the geostrophic current during the First-inter monsoon. During this season, a giant cyclonic eddy (D1) has formed in the middle part of the southern SCS, approximately at $\sim 9^{\circ} \mathrm{N}, 113^{\circ} \mathrm{E}$ and in the Gulf of Thailand (D2) approximately at $\sim 9^{\circ} \mathrm{N}, 102^{\circ} \mathrm{E}$. Meanwhile, an anti-cyclonic eddy (U1) exists around Natuna Island during this season. Figure 9 shows the mean of monthly geostrophic current during the Second-inter monsoon. During this season, the current circulation pattern at the coastal Sarawak is experiencing the same behaviour as during the SW monsoon. A weak cyclonic eddy (U2) has formed near to Sarawak coastal region current. The cyclonic eddy (D2), which formed during SW monsoon, still exists during this season. The summary of the upwelling and downwelling locations is in Table 5 .

Table 5. Summary of upwelling and downwelling over SSCS for each Monsoon

\begin{tabular}{lll}
\hline Season & Behaviour & Location \\
\hline NE & Upwelling (U1) & $6^{\circ} \mathrm{N}, 110^{\circ} \mathrm{E}$ \\
NE & Downwelling (D1) & $9^{\circ} \mathrm{N}, 104^{\circ} \mathrm{E}$ \\
NE & Downwelling (D2) & $3^{\circ} \mathrm{N}, 105^{\circ} \mathrm{E}$ \\
SW & Upwelling (U1) & $4^{\circ} \mathrm{N}, 114^{\circ} \mathrm{E}$ \\
SW & Upwelling (U2) & $9^{\circ} \mathrm{N}, 103^{\circ} \mathrm{E}$ \\
SW & Downwelling (D1) & $5^{\circ} \mathrm{N}, 105^{\circ} \mathrm{E}$ \\
FIM & Downwelling (D1) & $9^{\circ} \mathrm{N}, 113^{\circ} \mathrm{E}$ \\
FIM & Downwelling (D2) & $9^{\circ} \mathrm{N}, 102^{\circ} \mathrm{E}$ \\
FIM & Upwelling (U1) & $3^{\circ} \mathrm{N}, 108^{\circ} \mathrm{E}$ \\
SIM & Downwelling (D1) & $3^{\circ} \mathrm{N}, 112^{\circ} \mathrm{E}$ \\
SIM & Upwelling (U1) & $7^{\circ} \mathrm{N}, 106^{\circ} \mathrm{E}$ \\
SIM & Downwelling (D1) & $6^{\circ} \mathrm{N}, 100^{\circ} \mathrm{E}$ \\
\hline
\end{tabular}

\section{Upwelling Interpretation based on Monthly} Climatology of Geostrophic Current Circulation

In order to analyse the ocean current pattern during a different month, the geostrophic current is computed based on the monthly climatology sea level anomaly for 5 years' duration, and the result is shown in Figure 10 until Figure 12. From January to March (Figures 10(a)-10(c)), the pattern of upwelling mimics the pattern during the Northeast monsoon
(NE), because during those months, it is clear that NE monsoon-influenced the pattern of the upwelling behaviour. However, at the start of April (Figure 10(d)), the current is almost inversed, where water flow moves northward. From here, it can be seen the presence of anti-cyclonic is taking place approximately $\left(8^{\circ} \mathrm{N} 110^{\circ} \mathrm{E}\right)$ and $\left(9^{\circ} \mathrm{N} 103^{\circ} \mathrm{E}\right)$. From there, it shows that a particular area during the month of April is downwelling. Apart from that, the coast of Sarawak shows an upwelling, where the current is forming a cyclonic pattern.

During May (Figure 11(a)), the upwelling can be seen from the coast of Johor to Terengganu, where the current at that area is a cyclonic eddy. However, in the figure, the presence of downwelling is also seen in the Gulf of Thailand and northeast of Natuna Island because the transition period of the northeast and southeast monsoon system is occurring, where the southwest of Karimata strait is forming (Akhir, 2012). For June, the upwelling can be seen at the Gulf of Thailand, where the current pattern forms a cyclonic eddy, which indicates the upwelling behaviour as shown in Figure 11(b). The upwelling can also be seen northwest of Sarawak and north of Sabah, in which the current is a cyclonic eddy as well. However, downwelling behaviour can also exist at approximately $\left(6^{\circ} \mathrm{N}, 105^{\circ} \mathrm{E}\right)$ where the current flows clockwise, which indicates anti-cyclonic eddy.

In July and August, as shown by Figure 11(c) and Figure 11(d), respectively, the pattern is almost symmetrical to one another, where the upwelling location is approximately at $\left(9^{\circ} \mathrm{N}, 113^{\circ} \mathrm{E}\right)$ and $\left(4^{\circ} \mathrm{N}, 113^{\circ} \mathrm{E}\right)$. However, the location of downwelling is similar to the downwelling location in June, which is $\left(6^{\circ} \mathrm{N}, 105^{\circ} \mathrm{E}\right)$. Downwelling was also seen in the Gulf of Thailand at approximately $\left(7^{\circ} \mathrm{N}, 104^{\circ} \mathrm{E}\right)$. During this month, the SW monsoon is dominant. The Karimata strait is moving freely northward because it propagates and changes direction northward when reaching the coastal current of Malaysia. As for September (Figure 12(a)), the presence of cyclonic eddy in the coastal area of Sarawak indicates the upwelling behaviour is taking place at $\left(5^{\circ} \mathrm{N}, 115^{\circ} \mathrm{E}\right)$, in which the upwelling dominates the northern part of Borneo. Meanwhile, in October (Figure 12(b)), there is an indication of upwelling at $\left(9^{\circ} \mathrm{N}, 114^{\circ} \mathrm{E}\right)$, where the current is a cyclonic eddy. However, downwelling also dominates the northern part of Borneo at $\left(5^{\circ} \mathrm{N}, 110^{\circ} \mathrm{E}\right)$. 



Figure 10. Geostrophic current during (a) January, (b) February, (c) March, and (d) April 

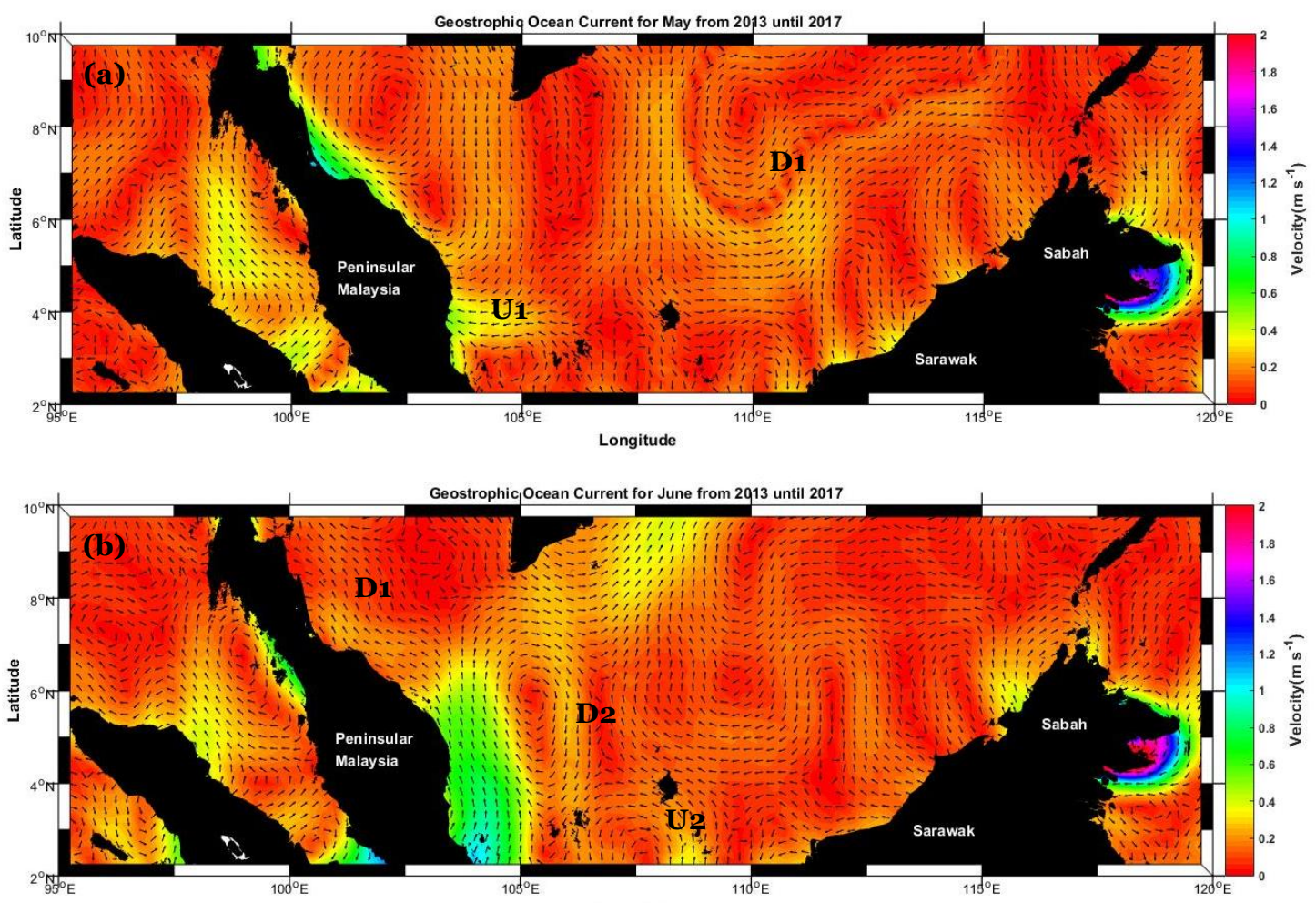

Longitude

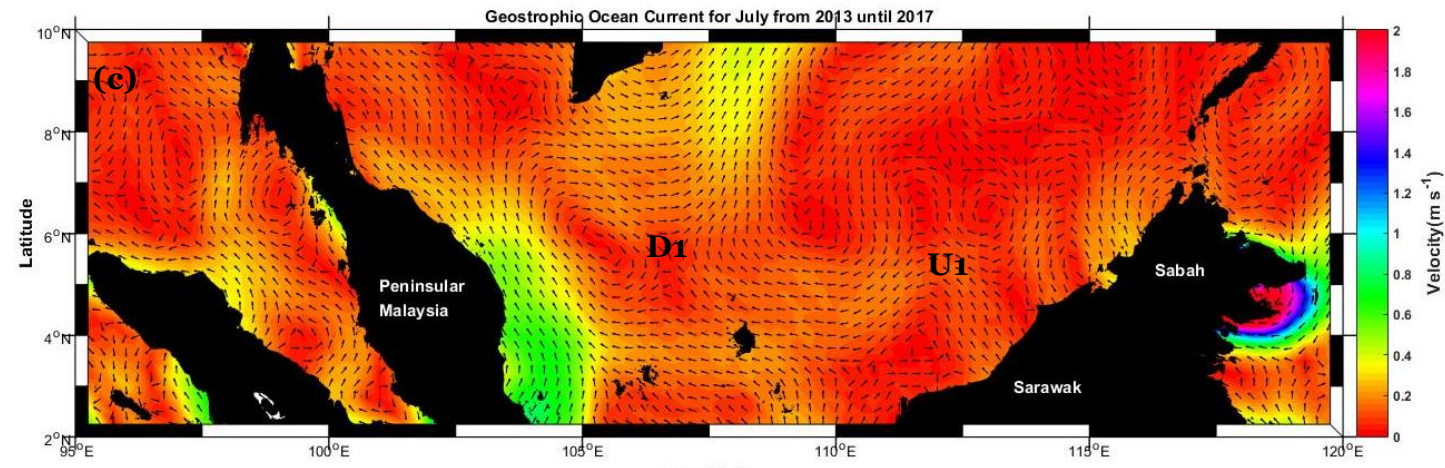

Longitude

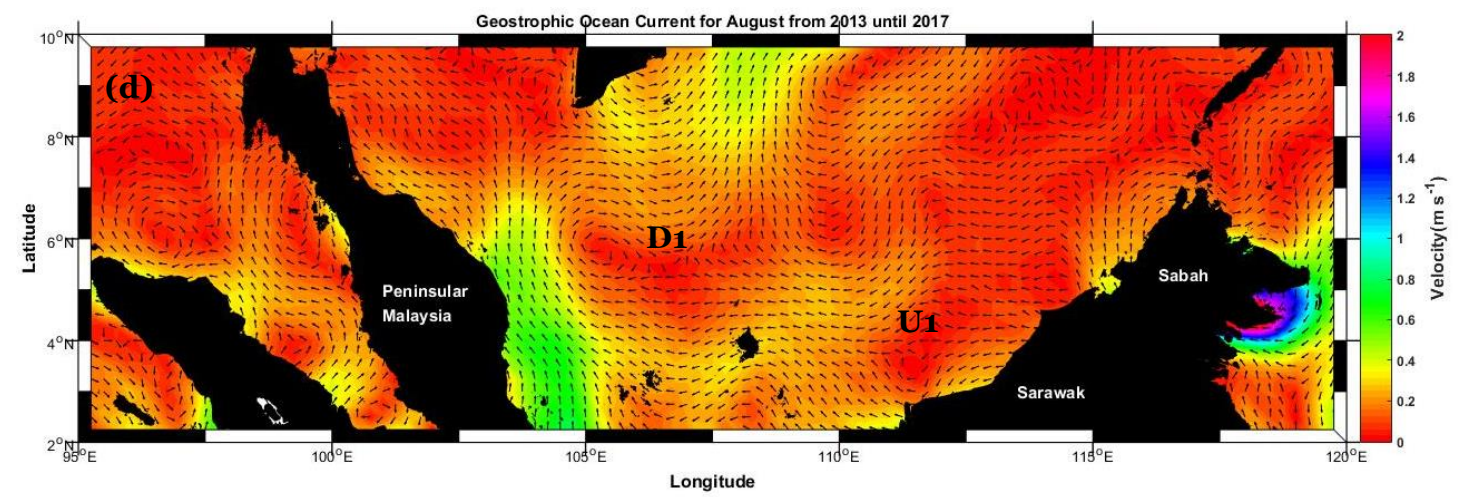

Figure 11. Geostrophic current during (a) May, (b) June, (c) July, and (d) August 

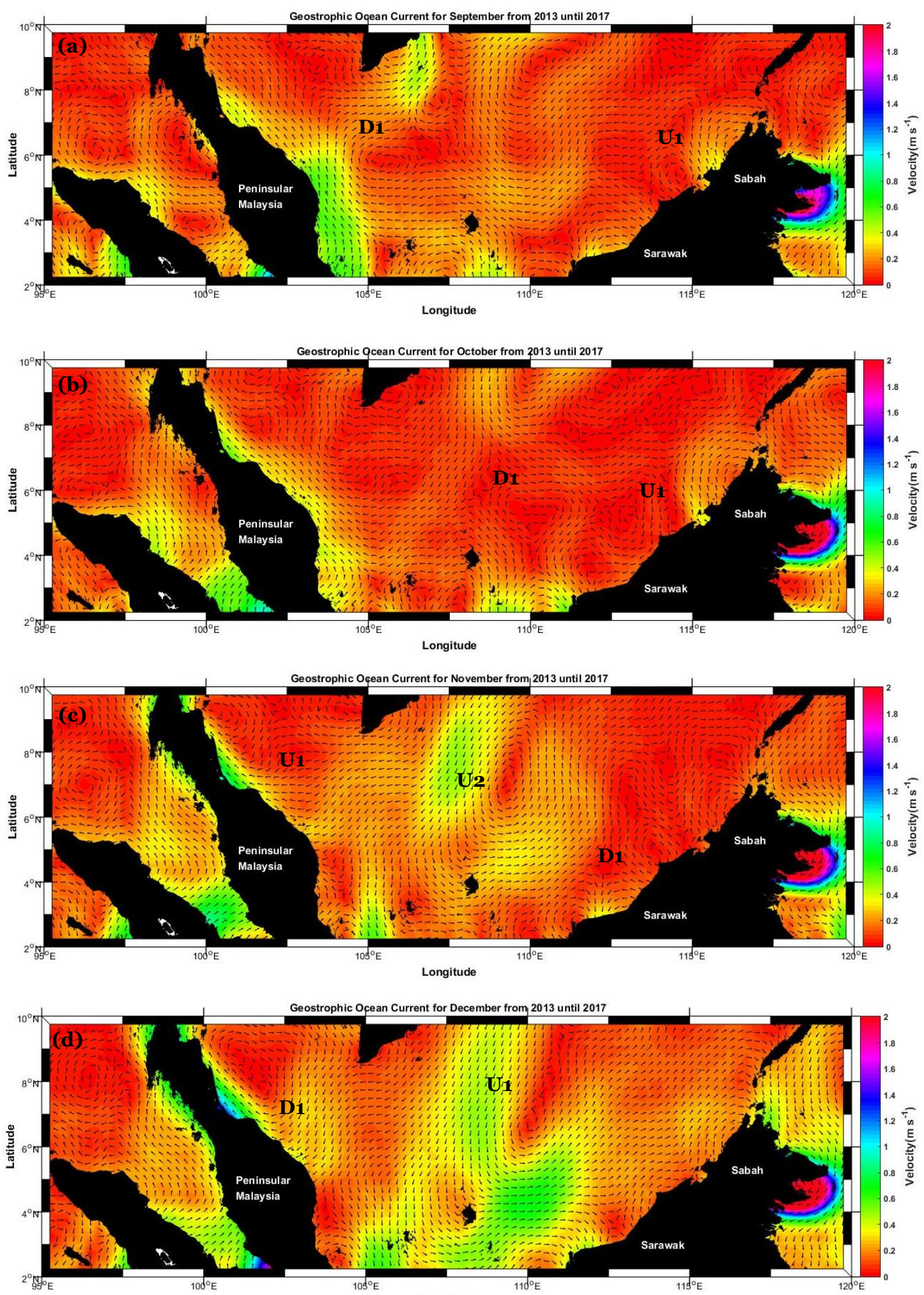

Figure 12. Geostrophic current during (a) September, (b) October, (c) November, and (d) December 
Figures 12(c) and (d) show ocean circulation patterns in November and December. The pattern during these two months is almost the same pattern with January and February. The summary of the upwelling and downwelling phenomenon is summarised in Table 6.

Table 6. Summary of upwelling and downwelling over SSCS for each Month

\begin{tabular}{|c|c|c|}
\hline Month & Behaviour & Location \\
\hline January & Upwelling (U1) & $7^{\circ} \mathrm{N} 110^{\circ} \mathrm{E}$ \\
\hline January & Downwelling (D1) & $9^{\circ} \mathrm{N} 101^{\circ} \mathrm{E}$ \\
\hline February & Upwelling (U1) & $7^{\circ} \mathrm{N} 110^{\circ} \mathrm{E}$ \\
\hline February & Downwelling (D1) & $9^{\circ} \mathrm{N} 101^{\circ} \mathrm{E}$ \\
\hline March & Upwelling(U1) & $7^{\circ} \mathrm{N} 110^{\circ} \mathrm{E}$ \\
\hline March & Downwelling (D1) & $9^{\circ} \mathrm{N} 113^{\circ} \mathrm{E}$ \\
\hline April & Downwelling (D1) & $7^{\circ} \mathrm{N} 112^{\circ} \mathrm{E}$ \\
\hline April & Downwelling (D2) & $3^{\circ} \mathrm{N} 106^{\circ} \mathrm{E}$ \\
\hline May & Downwelling (D1) & $7^{\circ} \mathrm{N} 112^{\circ} \mathrm{E}$ \\
\hline May & Upwelling (U1) & $3^{\circ} \mathrm{N} 105^{\circ} \mathrm{E}$ \\
\hline June & Downwelling (D1) & $9^{\circ} \mathrm{N} 104^{\circ} \mathrm{E}$ \\
\hline June & Downwelling (D1) & $6^{\circ} \mathrm{N} 105^{\circ} \mathrm{E}$ \\
\hline June & Upwelling(U1) & $3^{\circ} \mathrm{N} 108^{\circ} \mathrm{E}$ \\
\hline July & Downwelling(D1) & $6^{\circ} \mathrm{N} 105^{\circ} \mathrm{E}$ \\
\hline July & Upwelling(U1) & $4^{\circ} \mathrm{N} 112^{\circ} \mathrm{E}$ \\
\hline August & Downwelling (D1) & $6^{\circ} \mathrm{N} 115^{\circ} \mathrm{E}$ \\
\hline August & Upwelling(U1) & $4^{\circ} \mathrm{N} 112^{\circ} \mathrm{E}$ \\
\hline September & Downwelling(D1) & $6^{\circ} \mathrm{N} 106^{\circ} \mathrm{E}$ \\
\hline September & Upwelling(U1) & $5^{\circ} \mathrm{N} 115^{\circ} \mathrm{E}$ \\
\hline October & Upwelling(U1) & $9^{\circ} \mathrm{N} 114^{\circ} \mathrm{E}$ \\
\hline October & Downwelling(D1) & $5^{\circ} \mathrm{N} 110^{\circ} \mathrm{E}$ \\
\hline November & Upwelling(U1) & $9^{\circ} \mathrm{N} 102^{\circ} \mathrm{E}$ \\
\hline November & Upwelling (U2) & $7^{\circ} \mathrm{N} 108^{\circ} \mathrm{E}$ \\
\hline November & Downwelling (D1) & $5^{\circ} \mathrm{N} 113^{\circ} \mathrm{E}$ \\
\hline December & Upwelling (U1) & $7^{\circ} \mathrm{N} 108^{\circ} \mathrm{E}$ \\
\hline December & Downwelling(D1) & $9^{\circ} \mathrm{N} 102^{\circ} \mathrm{E}$ \\
\hline
\end{tabular}

\section{CONCLUSION}

The research aims to analyse the upwelling pattern based on the formation of cyclonic eddies in the southern region of the South China Sea by using multi-mission satellite altimetry derived geostrophic current. Five (5) years of averaged SLA from altimetric datasets have been used to derive the geostrophic current. Comparison of SLA with tidal data from 6 selected tide gauges shows that the sea level from both methods has a good correlation from 0.84 to
0.96, respectively. During NE monsoon, the movement of the water produces a large cyclonic gyre in the middle part of southern SCS, indicates that the upwelling phenomenon probably occurs in the region. During SW Monsoon, the features of circulation in the SCS almost the opposite direction to that seen during NE Monsoon and weaker. The large cyclonic gyre in the middle part of southern SCS has disappeared during this monsoon and was replaced by anticyclonic eddy. What is interesting to highlight here is that an anti-cyclonic eddy has formed near the east coast of Peninsular Malaysia. However, the eddy's existence probably needs further study to confirm its existence of the eddy. The geostrophic current during the first and second inter-monsoon are weaker than during NE Monsoon and SW Monsoon. The circulation pattern in the SSCS during the second inter-monsoon is rather complex than the first intermonsoon. Overall, the existence of the cyclonic eddies detected through the geostrophic current pattern can indicate the existence of the upwelling area. However, other factors should be considered in further study to identify or reconfirm this phenomenon.

\section{ACKNOWLEDGEMENT}

The author would like to thank TU Delft, Altimetric LLC for providing altimetry data through the Radar Altimetry Database system. Besides, thanks to the Department of Survey and Mapping Malaysia (DSMM) for providing the tidal data via the Permanent Service for Mean Sea Level website. We thank the Ministry of Higher Education (MOHE), Malaysia, and Universiti Teknologi MARA (UiTM) for their financial funding through FRGS 2018 (Reference code: FRGS/1/2018/WABo8/UITM/03/1). 


\section{REFERENCES}

Abazu, IC, Din, AHM \& Omar, KM 2017, 'Mean dynamic topography over Peninsular Malaysian seas using multimission Satellite Altimeter', J. Appl. Remote Sens., vol. 11, no. 2. doi: 10.1117/1.JRS.11.026017.

Akhir MF 2012, 'Surface circulation and temperature distribution of southern South China sea from Global Ocean Model (OCCAM)', Sains Malaysiana, vol. 41, no. 6(2012), pp. 701-714.

Akhir, M, Daryabor, F, Husain, M, Tangang, F \& Qiao, F 2015, 'Evidence of upwelling along Peninsular Malaysia during Southwest Monsoon', Open Journal of Marine Science, vol. 5, pp. 273-279.

Archiving, validation and interpretation of satellite oceanographic data AVISO 2019, Altimetry Principle (Topex/Poseidon satellite), viewed 2 February 2019, <https://www.aviso.altimetry.fr/gallery/entry_21_ altimetry_principle_topex_poseidon_satellite_.html>.

Chafik, L, Nilsen, JEØ, Dangendorf, S, Reverdin, G \& Frederikse, T 2019, 'North Atlantic Ocean circulation and decadal sea level change during the altimetry era', Scientific Reports, vol. 9, no. 1. doi: 10.1038/s41598-01837603-6.

Chelton, DB, Ries, JC, Haines, BJ, Fu, L-L \& Callahan, PS 2001, Satellite altimetry, Satellite Altimetry and Earth Sciences, vol. 69, pp. 1-131.

Cropper, TE, Hanna, E \& Bigg, GR 2014, 'Spatial and temporal seasonal trends in coastal upwelling off Northwest Africa, 1981-2012', Deep-Sea Research Part I: Oceanographic Research Papers, vol. 86, pp. 94-111. doi: 10.1016/j.dsr.2014.01.007.

Desbiolles, F, Blanke, B, Bentamy, A \& Grima, N 2014, 'Origin of fine-scale wind stress curl structures in the Benguela and Canary upwelling systems', Journal of Geophysical Research: Oceans, vol. 119, no. 11, pp. 79317948. doi: 10.1002/2014JC010015.

Din, AHM, Ses, S, Omar, KM, Naeije, M, Yaakob, O \& Pa'suya, MF 2014, 'Derivation of sea level anomaly based on the best range and geophysical corrections for Malaysian seas using Radar Altimeter Database System (RADS)', Jurnal Teknologi, vol. 71, no. 4.

Din, AHM, Hamid, AIA, Yazid, NM, Tugi, A, Khalid, NF, Omar, KM \& Ahmad, A 2017, 'Malaysian sea water level pattern derived from 19 years tidal data', Jurnal Teknologi, vol. 79, no. 5, pp. 137-145. doi: 10.11113/jt.v79.9908.

Din, AHM, Zulkifli, NA, Hamden, MH, Aris, WAW 2019, 'Sea level trend over Malaysian seas from multi-mission Satellite Altimeter and vertical land motion corrected tidal data', Advances in Space Research, vol. 63, no. 11, 1 June 2019, pp. 3452-3472. doi: 10.1016/j.asr.2019.02.022.

Djakouré, S, Penven, P, Bourlès, B, Veitch, J \& Koné, V 2014, 'Coastally trapped eddies in the north of the Gulf of Guinea', Journal of Geophysical Research: Oceans, vol. 119, no. 10, pp. 6805-6819. doi: 10.1002/2014JC010243.

Ducet, N, Le Traon, PY \& Reverdin, G 2000, 'Global highresolution mapping of ocean circulation from the combination of TOPEX/POSEIDON and ERS-1/2', Journal of Geophysical Research, vol. 105(C8), pp. 1947719498.

Fu, LL \& Chelton, D 2001, Large-scale ocean circulation, in: Fu, L.L., Cazenave, A. (Eds.), Satellite Altimeter and earth sciences: A handbook of techniques and applications, Academic Press, pp. 133-169.

Faghmous, JH, Frenger, I, Yao, Y, Warmka, R, Lindell, A \& Kumar, V 2015, 'A daily global mesoscale ocean eddy dataset from Satellite Altimeter', Scientific Data, 2. doi: 10.1038/sdata.2015.28.

Gan, J, Liu, Z \& Liang, L 2016, 'Numerical modeling of intrinsically and extrinsically forced seasonal circulation in the China Seas: A kinematic study', Journal of Geophysical Research: Oceans, vol. 121, no. 7, pp. 4697-4715. doi: 10.1002/2016JCo11800.

Hamid, AIA, Din, AHM, Hwang, C, Khalid, NF, Tugi, A, \& Omar, KM 2018, 'Contemporary Sea level rise rates around Malaysia: Altimeter data optimization for assessing coastal impact', Journal of Asian Earth Sciences, vol. 166, pp. 247-259. doi: 10.1016/j.jseaes.2018.07.034.

Hyem, T \& Kvale, O (eds) 1977, Physical, chemical and biological changes in food caused by thermal processing, 2nd edn, Applied Science Publishers, London, UK.

Junker, T, Schmidt, M \& Mohrholz, V 2015, 'The relation of wind stress curl and meridional transport in the Benguela upwelling system', Journal of Marine Systems, vol. 143, pp. 1-6. doi: 10.1016/j.jmarsys.2014.10.006.

Kumar, P \& Garde, RJ 1989, 'Potentials of water hyacinth for sewage treatment', Research Journal of Water Pollution Control Federation, vol. 30, no. 10, pp. 291-294. 
Kuo, NJ, Zheng, Q \& Ho, CR 2000, 'Satellite observation of upwelling along the Western Coast of the South China sea', Remote Sensing of Environment, vol. 74, pp. 463-470. doi: 10.1016/soo34-4257(oo)oo138-3.

Le Traon, PY, Hernandez, F, Rio, MH \& Davidson, F 2003, 'How operational oceanography can benefit from dynamic topography estimates as derived from altimetry and improved geoid', Space Science Reviews 07-2003, vol. 108, no. 1-2, pp. 239-249.

Maximenko, N, Niiler, P, Rio, M-H, Melnichenko, O, Centurioni, L, Chambers, D, Zlotnicki, V \& Galperin, B 2009, 'Mean dynamic topography of the ocean derived from satellite and drifting buoy data using three different techniques', Journal of Atmospheric and Oceanic Technology, vol. 26, no. 9, pp. 1910-1919.

McColloch, LP, Cook, HT \& Wright, WR 1968, Market diseases of tomatoes, peppers and egg-plants, Agriculture Handbook no. 28, United States Department of Agriculture, Washington, DC.

Morimoto, A, Yoshimoto, $\mathrm{K}$ \& Yanagi, T 2000, 'Characteristics of sea surface circulation and Eddy field in the South China sea revealed by satellite altimetric data', Journal of Oceanography, vol. 56, no. 3, pp. 331-344.

Naeije, M, Schrama, E \& Scharroo, R 2000, 'The radar altimeter database system project rads', in Proceedings of the 2000 Geoscience and Remote Sensing Symposium, 2000, Proceedings IGARSS 2000, IEEE 2000 International: IEEE, pp. 487-490.

Ndah, AB, Becek, K \& Dagar, L 2016, 'A review of coastal upwelling research in the South China sea: Challenges, Limitation and Prospects', International Journal of Earth and Atmospheric Science, vol. 3, no. 4, pp. 63-72.

Ndah, AB, Dagar, L \& Becek, K 2017, 'Multi-temporal patterns of upwelling-downwelling dynamics in the South China Sea based on a 47-year time-series of the NOAAERD upwelling index', Regional Studies in Marine Science, vol. 16, pp. 225-239. doi: 10.1016/j.rsma.2017.08.017.

Pa'suya, MF, Omar, KM, Peter, BN \& Din, AHM 2014a, 'Ocean surface circulation along peninsular Malaysia's eastern continental shelf from nineteen years satellite altimeter data, vol. 59 - 64', Conference: 2014 IEEE 5th Control and System Graduate Research Colloquium, at Shah Alam.

Pa'suya, MF, Omar, KM, Peter, BN \& Din, AHM 2014b, 'Seasonal Sea surface circulation in the Northwest region off the Borneo Island based on nineteen years satellite altimetry data', in Lecture Notes in Geoinformation and
Cartography, pp. 189-200, Springer Science and Business Media Deutschland Gmb. doi: 10.1007/978-3-319-036441_14.

Pickard, GL \& Emery, WJ 1990, Descriptive physical oceanography: An introduction, $5^{\text {th }}$ edn, ButterworthHeinemann, 320 pages.

Permanent Service Mean Sea Level 2019, Tide Gauge Data, retrieved from <http://www.psmsl.org/data/obtaining/>.

Renault, L, Molemaker, MJ, Mcwilliams, JC, Shchepetkin, AF, Lemarié, F, Chelton, D, Illig, S \& Hall, A 2016, 'Modulation of wind work by oceanic current interaction with the atmosphere', Journal of Physical Oceanography, vol. 46, no. 6, pp. 1685-1704. doi: 10.1175/ JPO-D-150232.1.

Rio, MH, Santoleri, R, Bourdalle-Badie, R, Griffa, A, Piterbarg, L \& Taburet, G 2016, 'Improving the altimeterderived surface currents using high-resolution sea surface temperature data: A feasability study based on model outputs', Journal of Atmospheric and Oceanic Technology, vol. 33 , no. 12, pp. 2769-2784. doi: 10.1175/JTECH-D-160017.1.

Science Education Earth Observation for High School SEOS 2019, Ocean Currents: Types of Upwelling, viewed 2 February 2019, < project.eu/oceancurrents/oceancurrents-c04-s01po1.html>.

Thomas, S 1997, Guide to personal efficiency, Adelaide University, viewed 6 January 2004, $<$ http://library.adelaide.

edu.au/ sthomas/papers/perseff.html>.

Tornado 2019, Divergence in the Ocean Surface, retrieved from

<http://tornado.sfsu.edu/geosciences/classes/m415 715/ monteverdi/Divergence/Upwelling/Deviations from geo strophy divergence.html $>$.

Umaroh, Anggoro, S \& Muslim 2017, The dynamics of sea surface height and geostrophic current in the Arafura Sea, in IOP Conference Series: Earth and Environmental Science, vol. 55, Institute of Physics Publishing.

Uti, MN, Din, AHM \& Omar, AH 2013, 'Reliability of wind speed data from satellite altimeter to support wind turbine energy', Paper presented at the International Archives of the Photogrammetry, Remote Sensing and Spatial Information Sciences - ISPRS Archives, vol. 42(4W5), pp. 215-224. doi:10.5194/isprs-archives-XLII-4-W5-215-2017. Villanoy, CL, Cabrera, OC, Yñiguez, A, Camoying, M, de Guzman, A, David, LT \& Lament, PF 2011, 'Monsoon- 
driven coastal upwelling off Zamboanga peninsula, Philippines', Oceanography, vol. 24, no. 1, pp. 156-165. doi: 10.5670/oceanog.2011.12.

Wang, Z, Li, Q, Sun, L, Li, S, Yang, Y \& Liu, S 2015, 'The most typical shape of oceanic mesoscale eddies from global satellite sea level observations', Frontiers of Earth Science, vol. 9, no. 2, pp. 202-208. doi: 10.1007/s11707-014-0478Z.

Xie, SP, Xie, Q, Wang, D \& Liu, WT 2003, 'Summer upwelling in the South China Sea and its role in regional climate variations', Journal of Geophysical Research: Oceans, vol. 108, no. 8. doi: 10.1029/2003jc001867.

Yan, Y, Ling, Z \& Chen, C 2015, 'Winter coastal upwelling off northwest Borneo in the South China Sea', Acta Oceanologica Sinica, vol. 34, no. 1, pp. 3-10. doi: 10.1007/s13131-015-0590-2.

Yie, WS, Hartstein, ND, Maxey, JD, Bin Bakar, MS \& Hui, LC 2021, 'Coastal upwelling along the west coast of Sabah and its impact on coastal aquaculture management', Ocean and Coastal Management, vol. 211. doi: 10.1016/j.ocecoaman.2021.105781.

Zhuang, W, Xie, SP, Wang, D, Taguchi, B, Aiki, H \& Sasaki, $\mathrm{H}$ 2010, 'Intraseasonal variability in sea surface height over the South China Sea', Journal of Geophysical Research, vol. 115(C4). doi: 10.1029/2009JCo05647. 